\title{
LEGITIMACY
}

Ambiguities of Political Success or Failure in East and Southeast Asia 
This page intentionally left blank 
Series on Contemporary China - Vol. 1

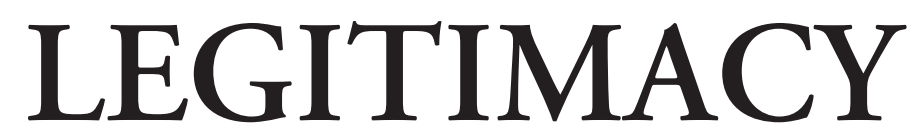

Ambiguities of Political Success or Failure in East and Southeast Asia

\author{
edited by \\ Lynn White
}

Princeton University, USA 
Published by

World Scientific Publishing Co. Pte. Ltd.

5 Toh Tuck Link, Singapore 596224

USA office: 27 Warren Street, Suite 401-402, Hackensack, NJ 07601

UK office: 57 Shelton Street, Covent Garden, London WC2H 9HE

British Library Cataloguing-in-Publication Data

A catalogue record for this book is available from the British Library.

Copyright (C) 2005 by World Scientific Publishing Co. Pte. Ltd.

All rights reserved. This book, or parts thereof, may not be reproduced in any form or by any means, electronic or mechanical, including photocopying, recording or any information storage and retrieval system now known or to be invented, without written permission from the Publisher.

For photocopying of material in this volume, please pay a copying fee through the Copyright Clearance Center, Inc., 222 Rosewood Drive, Danvers, MA 01923, USA. In this case permission to photocopy is not required from the publisher.

Typeset by Stallion Press

Email: enquiries@stallionpress.com

Printed in Singapore. 


\section{SERIES ON CONTEMPORARY CHINA}

\section{Series Editors}

Joseph Fewsmith (Boston University)

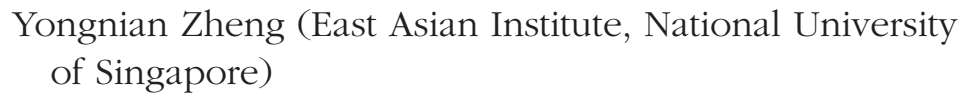

\section{Advisory Board Members}

Tun-jen Cheng (College of William and Mary)

Jane Duckett (University of Glasgow)

James Tang (University of Hong Kong)

Gungwu Wang (East Asian Institute, National University

of Singapore)

Lynn White (Princeton University)

Dali Yang (University of Chicago)

Ji You (University of New South Wales)

This series showcases the most significant and lasting contributions to scholarship in the studies of China's politics, society, and culture whether for general readers or specialists. Each of the volumes is a quality work by a leading scholar or scholars in the field and may take the form of a reasearch monograph, a multi-author edited volume, a conference proceeding, a textbook, or an annual review, among others. While the focus is on China, the series does not lose sight of the interplay of other regional and global forces and their influence and impact on China.

\section{Forthcoming Title}

China under the Fourth Generation Leadership: Opportunities, Dangers, and Dilemmas, edited by Tun-jen Cheng, Jacques deLisle and Deborah Brown. 
This page intentionally left blank 


\section{Contents}

List of Contributors $\quad$ ix

Introduction - Dimensions of Legitimacy 1

Lynn White

1) Political Legitimacy in Malaysia: 29

Regime Performance in the Asian Context

Bruce Gilley

2) The Basis of Political Legitimacy in LateAuthoritarian Taiwan

David Dabua Yang

3) Political Trust in China: Forms and Causes 113

Zhengxu Wang

4) Nationalism and the Problem of

Political Legitimacy in China

Jungmin Seo

5) Political Legitimacy in Reform China:

Between Economic Performance and Democratization Yongnian Zheng and Liang Fook Lye 


\section{viii Contents}

6) Legitimating Rhetorics and Factual

Economies in a South Korean Development Dispute Robert Oppenheim

7) Policy Legitimacy as a Determinant of Policy Outputs: Japan's Case

Takayuki Sakamoto

Index 


\section{List of Contributors}

Bruce Gilley is a doctoral student in politics at Princeton University. His current research is centered on the legitimacy of states in crossnational comparison, paying particular attention to the mediation of pluralism. He is the author of three books on China, most recently China's Democratic Future (Columbia University Press, 2004), and co-editor of a forthcoming volume entitled Comparing China and India: New Paradigms for Asia's Giants.

Liang Fook Lye is a Research Officer at the East Asian Institute of the National University of Singapore. He has conducted research on China's central-local relations, technocratic leadership, media reforms, and political legitimacy. He was part of a team that completed a study about the Singapore-Suzhou Industrial Park. He has also co-authored articles related to China's leadership transition, political reform, and crisis management. He compiled the index for the present book.

Robert Oppenheim is an anthropologist who teaches Korean topics in the Department of Asian Studies, University of Texas at Austin. His work focuses variously on Kyŏngju and the contemporary politics of history, place-making and locality, and the history of anthropology. 
Takayuki Sakamoto is an assistant professor of political science at Southern Methodist University. His research focuses on the comparative political economy of industrial democracies and Japanese politics. He is currently conducting a cross-national study of economic policy and performance in OECD countries, and also a study of the Japanese political economy and its changes over the past three decades. His articles have appeared in Comparative Political Studies, European Journal of Political Research, and Party Politics, and he is the author of Building Policy Legitimacy in Japan: Political Behavior beyond Rational Choice (Macmillan/St. Martin's Press, 1999).

Jungmin Seo is an assistant professor in the Department of Political Science at the University of Hawaii at Manoa, where he teaches Chinese and Korean politics. His main research interest focuses on the various forms of nationalism in contemporary East Asia.

Zhengxu Wang is finishing his Ph.D. from the University of Michigan's Department of Political Science. His areas of study include comparative democratization, political attitudes and behaviors, and China and Asian politics. He has been publishing in international journals and edited volumes and is currently preparing articles for journals including Foreign Affairs and the Journal of Democracy.

Lynn T. White III teaches in the Politics Department, Woodrow Wilson School, and East Asian Studies Program at Princeton. He edited the present volume while at the Centre of Asian Studies, University of Hong Kong. His books include Careers in Shanghai about the 1950s, Policies of Chaos about the Cultural Revolution, and Unstately Power about the origins of reforms. He has also written articles concerning Hong Kong and cross-Strait relations. His main current book project is about the effects of economic booms on local political structures in China and Southeast Asia.

David Dahua Yang is a doctoral candidate in the Politics Department at Princeton University. His dissertation explores the 
linkage between modes of political development and socioeconomic organization, drawing upon the comparative experiences of Taiwan, Singapore, and South Korea. He has also published various articles on Chinese politics and research methodology. Yang holds an MBA in Economics and worked as a financial software developer before returning to graduate school.

Yongnian Zheng is a Senior Research Fellow at the East Asian Institute (EAI) of the National University of Singapore and co-editor of China: An International Journal. His research focus is on China's domestic political economy and its external relations. His papers have appeared in journals such as Comparative Political Studies, Political Science Quarterly, and Third World Quarterly. His books include Discovering Chinese Nationalism in China (Cambridge University Press, 1999), Globalization and State Transformation (Cambridge University Press, 2004) and Will China Become Democratic? Elite, Class and Regime Transition (2004). He has also co-edited many volumes including Reform, Legitimacy and Dilemmas (2000) and Bringing the Party Back In (2004). 